\title{
Waste management practices and profitability analysis of poultry farming in Mymensingh district: A socioeconomic study
}

\author{
Manasi Modak ${ }^{1}$, Emdadul Haque Chowdhury ${ }^{2}$, M. Saidur Rahman ${ }^{3}$ and ${ }^{\bowtie}$ M. Nahid Sattar ${ }^{3}$ \\ ${ }^{1}$ Interdisciplinary Institute for Food Security, Bangladesh Agricultural University, Mymensingh-2202, Bangladesh \\ ${ }^{2}$ Department of Pathology, Bangladesh Agricultural University, Mymensingh-2202, Bangladesh \\ ${ }^{3}$ Department of Agricultural Economics, Bangladesh Agricultural University, Mymensingh-2202, Bangladesh
}

\begin{tabular}{|c|c|}
\hline ARTICLE INFO OPEN ${ }^{A a}$ & \\
\hline $\begin{array}{l}19 \\
19\end{array}$ & \multirow{3}{*}{$\begin{array}{l}\text { Poultry manure is a hazard to the environment and health due to the release of toxic substances as well as } \\
\text { pathogenic microorganisms. The present study was undertaken to assess the current scenario of poultry } \\
\text { waste management considering its social as well as environmental and health hazards. A questionnaire } \\
\text { based survey was conducted in } 36 \text { commercial poultry farms (which included } 15 \text { broiler, } 14 \text { layer, } 3 \\
\text { cockerel and } 4 \text { mixed farms) in Mymensingh district from February to June } 2016 \text {. Most of the broiler and } \\
\text { layer farms had between } 500 \text { to } 2000 \text { birds, while most of the cockerel farms had between } 3000 \text { to } 4000 \\
\text { birds. The study showed that } 69 \text { percent of the poultry farmers were unaware of the health and } \\
\text { environmental problems of the poultry waste. Majority of the small scale farmers disposed their droppings } \\
\text { to fish ponds ( } 31 \text { percent) and agricultural farms ( } 16 \text { percent) directly, while only } 6 \text { percent farmers used } \\
\text { those droppings in biogas plant. However, } 53 \text { percent farmers had knowledge about hygienic handling of } \\
\text { poultry dropping, although only } 19 \text { percent of them used protective gloves during dropping handling. The } \\
\text { profitability analysis revealed that average variable cost and fixed cost per farm per year were TK. TK. } \\
2,17,355 \text { and TK. } 3,93,106 \text {, respectively. The benefit cost ratio per farm per year poultry farming was } \\
1.55 \text {. Considering the findings, it is suggested that proper poultry waste management could be highly } \\
\text { beneficial for the farmers. On the other hand, improper dispose of poultry litter could be a cause for social, } \\
\text { environmental and public health hazard. }\end{array}$} \\
\hline & \\
\hline & \\
\hline
\end{tabular}

Copyright:

(c) (7)

(92019 by authors and BAURES. This work is licensed under the Creative Commons Attribution International License (CC By 4.0).

\section{Introduction}

In Bangladesh, more than half of the population is based on agricultural and livestock farming. In case of livestock, poultry sub-sector is an important avenue in fostering agricultural growth, improve food security and employs over 5 million people, making it the second largest source of rural jobs (IFC, 2014). Poultry population in Bangladesh is estimated about 304.17 million where chicken population is about 255.31 million (Hamid et al., 2017). Also, it is estimated that approximately 1,560,000 metric tonnes of poultry waste is produced in Bangladesh each year (Miah et al., 2016). Analysis has shown that poultry litter contains potentially valuable plant and animal nutrients, including nearly 30 percent crude protein and high levels of minerals and some heavy metals (Zinn et al., 1996). Poultry litter has useful properties as a fertilizer and soil amendment and has been used for many years in the production of a range of crops and products for human consumption (Runge et al., 2007). Poultry waste can also be used positively as feather meal, biodiesel, electricity generator, biodegradable plastic, biogas, vermicompost, etc. However, poultry manure is a potential hazard to the environment due to the release of nitrate and phosphate to the streams, ponds, and ground water; as well as ammonia, hydrogen sulphide gas in the air (Dai et al., 2015) due to inappropriate disposal of poultry waste. Poultry litter can also contain a number of pathogens and other materials that are a potential risk to public health (heavy metals, antimicrobial agents including the genes that confer resistance to these agents and endocrine disruptors) (Runge et al., 2007).

Dumping is not a scientific disposal of poultry manure, because there is an anaerobic condition inside and due to increasing emission of harmful pollutants like ammonia, phenol, toluene, methanol, etc., in the atmosphere results in obnoxious odor decreasing bird's productivity (Thyagarajan et al., 2014). Crude dumping of this waste is not only unattractive but also environmentally harmful. Development of the waste management plan is a sound investment to avoid environmental issues. However appropriate poultry waste management can help to alleviate environmental and health hazards by killing most human and animal pathogens including $E$. coli and Salmonella (Griffiths, 2007).

Home gardens are integral part of rural households in Bangladesh. But, when fresh poultry manure is applied to soil there are a range of potential environmental problems which have received attention, including nitrate and phosphate leaching, carbon runoff, bacterial

\section{Cite this article}

Modak, M., Chowdhury, E.H., Rahman, M.S. and Sattar, M.N. 2019. Waste management practices and profitability analysis of poultry farming in Mymensingh district: A socioeconomic study. Journal of Bangladesh Agricultural University, 17(1): 50-57. https://doi.org/10.3329/jbau.v17i1.40663 
contamination, nuisance insect breeding and greenhouse gas emission. So, it is alarming that due to unconsciousness and lack of proper disposing guidelines for these wastes, many farmers directly apply these to the agricultural lands and ponds which cause a major contributing and significant factor to pathogenic microbial hazards (Sarker et al., 2009).

Due to lack of sufficient information on the droppings disposal, the present study is undertaken to analyze the droppings disposal and the precautions that need to be adapted in preventing environmental pollution and health hazards.

Therefore, the specific objectives of the study are:

(i) to evaluate the current status of the poultry waste management in the study area;

(ii) to estimate the profitability of poultry production; and

(iii) to assess environmental and health threats related to poultry waste.

\section{Materials and Methods}

A structured questionnaire based survey was conducted in 36 commercial poultry farms in Sadar and Trishal Upazilas of Mymensingh district during February to June 2016 to evaluate the objectives of the study. The sample farms were selected purposively, based on the objectives of the study. The study considers all type of poultry farms like broiler, layer, and cockerel. It was a survey type experiment and data were collected from primary sources and accomplished by direct interviews with the respondent. Data were collected on socioeconomic characteristics of sampled farmers that included level of education, duration of farming, and training on poultry farm management etc.; environmental and health hazard awareness of poultry litter among farmers; poultry litter management system, constraints of waste management and also economic information of poultry farming system. All the quantitative data were encoded in Microsoft Excel program and then analyzed to determine profitability. Secondary data were collected from Bangladesh Bureau of Statistics (BBS), Bangladesh Economic Review, different relevant national and international journals, and newspaper.

The following equation was used to estimate profitability in the study.

$\Pi=\mathrm{P}_{\mathrm{b}} \mathrm{Q}_{\mathrm{b}}-\sum^{\mathrm{n}}\left(\mathrm{Px}_{\mathrm{i}} \mathrm{X}_{\mathrm{i}}\right)-\mathrm{TFC}$

Where,

$\Pi \quad=$ Profit (Tk./year/farm);

$\mathrm{P}_{\mathrm{b}} \quad=$ Per unit price of poultry product $(\mathrm{Tk} . / \mathrm{kg})$;

$\mathrm{Q}_{\mathrm{b}} \quad=$ Quantity of poultry product (kg/year/farm)

$\mathrm{P}_{\mathrm{xi}}=$ Per unit price of $\mathrm{i}^{\text {th }}$ (variables) inputs used in the broiler farm $(\mathrm{Tk} . / \mathrm{kg})$;

$\mathrm{X}_{\mathrm{i}}=$ Quantity of $\mathrm{i}^{\text {th }}$ (variables) inputs used in $\mathrm{kg}$; and

TFC $=$ Total fixed cost involved in broiler farm (Tk./year/farm).

\section{Results and Discussion}

Socioeconomic Profiles of the Sampled Farmers

The socioeconomic characteristics of sampled farmers are briefly discussed in this section.

Age of the farmer: Age of the respondents ranged from 20 to above 79 years. The highest proportion (33 percent) was in the age 40 to 49 year age groups and the lowest (3 percent) respondent's age were 60-79 age groups.

Gender: Gender is an important issue in the aspect of social, economical, and institutional aspects of the developing countries. Male owners 92 percent were predominant than female owner 8 percent. Hesitation in decision making and religious bindings on female employment appeared to be the major constraint for women to participate in poultry farming. While, males are actually owner of the poultry farm but in most cases, their wives provided similar labour to rural poultry production enterprise. Men mainly conducted the poultry sheds as women did cleaning, feeding and treatment of rural poultry.

Family size: On the basis of their family size, respondents were classified into "small family" up to four persons, "medium family" five-six persons and "large family" above seven persons. The percentages of family types in the study area were 63.89, 22.22 and 13.89 for small, middle and large, respectively. The farm families are larger on an average than the national average family size of 4.06 persons per household (BBS, 2017).

Level of education: Education creates knowledge, makes a person more confident, and enables him/her to think better. In the study area, the level of education undergoes six categories. These were can not sign, primary, secondary, higher secondary, graduation and post- graduation. There were only 3 percent respondent could not sign among the sample farmers. About 31 percent of respondents have primary education and there was also 22 percent of respondent have secondary level. The percentage under higher secondary level was 33 percent and interestingly 6 percent respondents were graduates. It is very important that there were 6 percent respondents who completed post-graduation as well. Hence, the literacy rate for this group of people was higher than the national rate of 65.6 percent for Bangladesh (BBS, 2017). This scenario suggested that many young and educated people are now interested to start poultry farming. Education broadens outlook of individuals and leads them to explore new ideas for better waste management.

Main occupation: The main occupations of the respondents are business and farming. The highest proportion of the respondents in the study area was only farming 55 percent, farming and business was 25 percent, service (government) was 3 percent, and service (NGO) was 3 percent. Farming \& others were 11 percent and business \& service (NGO) were 3 percent. It was found that business men are economically solvent enough to establish poultry farm. 
Duration of farming: The duration of farming ranged from 8 month to 22 years. Based on their duration of farming, the respondents were classified into six categories. The proportion of farmers in each category was 31 percent in 1 to 5 years, 8 percent in 6 to 10 years, 31 percent in 11 to 15 years, 22 percent in 16 to 20 years, 3 percent in 21 to 25 years and 6 percent in 26 to 30 years.

Training on poultry farm management: In the study area, 31 percent of the respondents were trained, while 69 percent were non-trained.

\section{Description of the Sampled Farms}

Farm type: There were four types of farm in this study. These were broiler (only), layer (only), cockerel and broiler (mixed) and cockerel (only). In this study highest 42 percent respondents were involved with broiler farming, 39 percent with layer and eight percent with cockerel and 11 percent with broiler and cockerel (mixed) farming.

Number of birds: The number of birds per farm is presented under the following six categories:

Table 1. Number of birds in the farm in the study area

\begin{tabular}{|c|c|c|c|c|c|c|}
\hline \multirow[t]{2}{*}{ Number of birds } & \multicolumn{2}{|c|}{ Layer } & \multicolumn{2}{|c|}{ Broiler } & \multicolumn{2}{|c|}{ Cockerel } \\
\hline & Number & Percentage & Number & Percentage & Number & Percentage \\
\hline Less than 500 & 1 & 7 & 4 & 21 & 1 & 14.3 \\
\hline $500-1000$ & 5 & 36 & 10 & 53 & 1 & 14.3 \\
\hline $1001-2000$ & 5 & 36 & 3 & 16 & 0 & 0.0 \\
\hline 2001-3000 & 0 & 0.0 & 1 & 5 & 1 & 14.3 \\
\hline $3001-4000$ & 1 & 7 & 1 & 5 & 3 & 42.8 \\
\hline Above 4000 & 2 & 14 & 0 & 0.0 & 1 & 14.3 \\
\hline Total & 14 & 100 & 19 & 100 & 7 & 100 \\
\hline
\end{tabular}

Source: Field survey, 2016

Quantity of litter: The quantity of litter is directly linked to the number of birds, age, and variation of diet, health of the birds and by farm management practices. According to field study, estimates of the manure excreted by 100 birds per day approximately ranged from $10-14 \mathrm{~kg}$ with an average of $12 \mathrm{~kg}$ for layer chickens and $11 \mathrm{~kg}$ for meat chickens, which is consistent with other studies (Collins et al., 1999; Williams et al., 1999). North and Bell (1990) suggested that variation in droppings production could be attributed to variation of feed consumption, water consumption, composition and form of feed, humidity and temperature.
Bedding materials of birds: Bedding materials of bird undergo into four categories. These were saw dust, husk, crop residue and others. Other refers various type of case which was used in layer farm and it was 39 percent. Husk and saw dusts were 41 percent and 20 percent, respectively. No farmer used crop residue as bedding material.

\section{Waste Management Practices in the Study Areas}

Schematic presentation of the waste disposal chain: A schematic diagram of how poultry waste is disposed, as observed in the study, is presented below. Detailed description of the process is given afterwards.

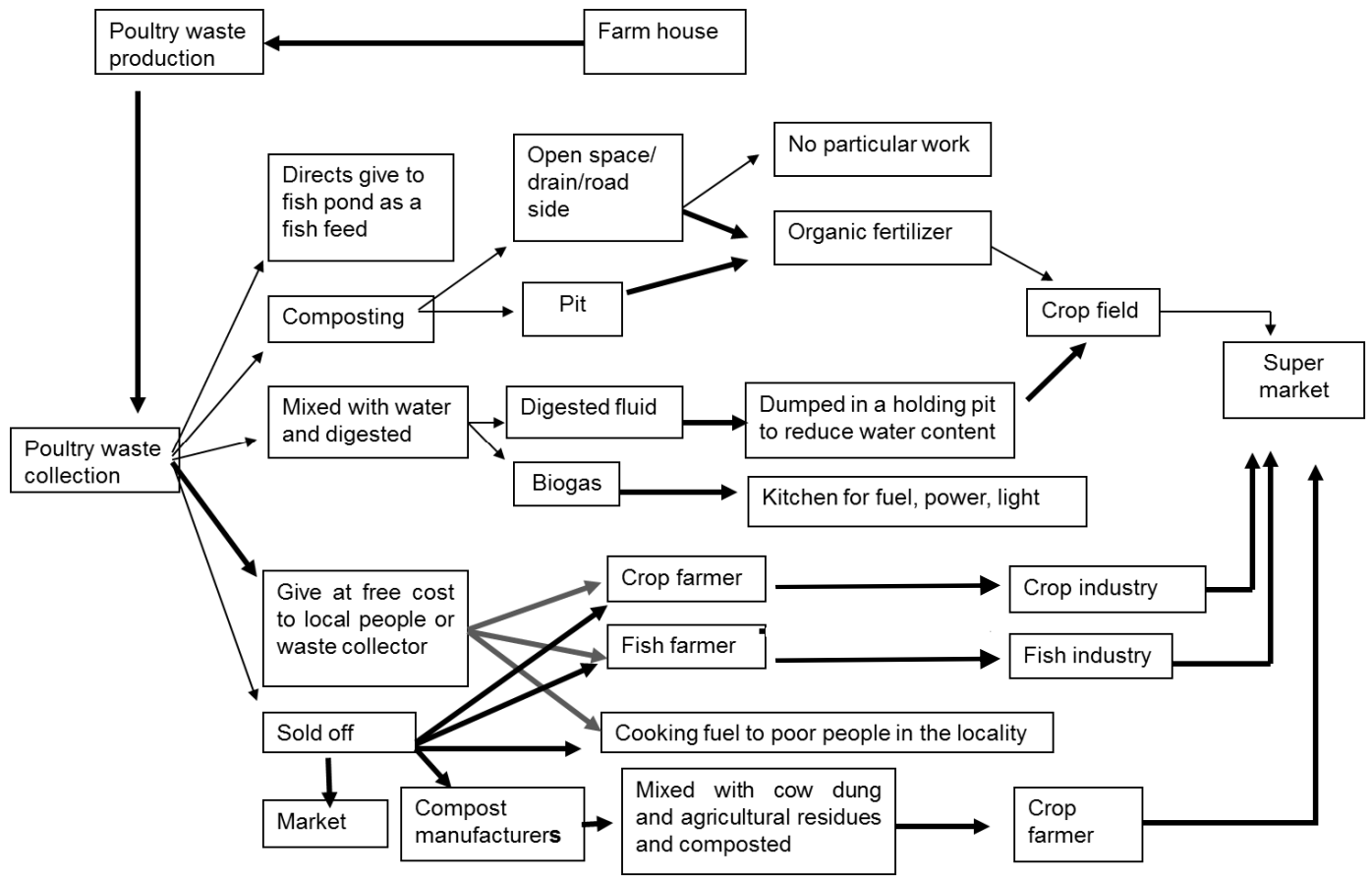

Fig 1. Schematic presentation of the waste disposal chain in the study areas 
Frequency of dropping collection: Frequency of collection of droppings depends on the number and type of birds. Normally, droppings of layer birds are cleaned daily or at alternate day where droppings of broiler are cleaned in once a week or once a cycle. Farmers reported that improper timing of dropping collection creates odor, nuisance, flies, etc. Droppings collection in alternative day seemed to be traditional in layer farm. But in this finding, most of the layer farms (31 percent) collect droppings daily and 19 percent collect at alternate day. There were also 19 percent and 31 percent droppings were collected in once a week and once a cycle respectively in broiler farm.

Time for cleaning: Most of the respondents prefer to clean the droppings in the morning ( 83 percent). While, 14 percent respondents clean the droppings at noon, and only 3 percent respondents clean at evening. The frequency of collection of droppings has a direct effect on the nutrient content of composition litter (Ellis et al., 2013). Cleaning droppings in the morning is appeared to be traditional and convenient (Amin et al., 2009). Regarding time required to clean droppings, 39 percent of the time 15-30 $\mathrm{min} /$ day was required, while, 44 percent of the time 31-90 min/day was required and 17 percent of the time more than $90 \mathrm{~min} /$ day was required. This variation might be related to difference of farm size, flock size, distance between shed \& site of disposal and efficiency of labour.

Cleaning responsibility: Among the cleaners, 3 percent were children, 39 percent were farm owner, 44 percent were laborer, 6 percent were spouse and 8 percent were laborer and farm owner.

It seems that poultry owners were also predominantly responsible for cleaning droppings. They suggested that labor wage act as a barrier for poultry production.

Tools for cleaning: Most of the respondents prefer shovel (belcha) for waste cleaning due to its availability and reasonable price. It was observed that 56 percent respondents used only shovel for cleaning droppings while, 14 percent used shovel and water for cleaning droppings. Another study also observed that shovel used for cleaning droppings was significantly higher than shovel and water $(\mathrm{P}<0.01)$ (Amin et al., 2009).

Water with pressure is needed for proper cleaning of poultry premises. Such facility is not available in Bangladesh. There were three percent respondents use only water for cleaning. Little amount of respondents use brush (3 percent) where five percent use shovel and brush simultaneously. Nineteen percent respondents use other tools.

Seasonal problem for cleaning: It was also found that 61 percent respondents reported dropping cleaning to be problematic in summer and 30 percent found it problematic in winter and 9 percent found in rainy season. Majority of the farmers considered that in summer season birds take more water, as a result droppings become more liquid and ultimately it creates problem to clean droppings. Damp litter creates problem in farms that experience high humidity in either summer or winter and in sheds using foggers for evaporative cooling in summer.

Site of disposal: Proper disposal plays a crucial role for environmental protection. Environments are polluted by the haphazard storage. In the findings, seven percent and three percent respondents were disposed the droppings in drain side and road side, respectively. Seventeen percent respondents disposed droppings for composting in pit while 10 percent farmers for composting in open space. Majority of the farmers (30 percent) dispose the fresh droppings to fish pond directly while 10 percent farmers preferred to dispose litter in agricultural farm directly. However, raw chicken manure can burn and damage plants and can contain pathogens that can harm people and animals (Saliga et al., 2013). In the study area, most of the large farm owners dispose raw chicken manure to the ponds. But, raw chicken manure is not suitable for feeding fish directly because of containing parasitic ovum, some toxic substance, germs and release of large amount of $\mathrm{N}$ and $\mathrm{P}$ to the water body which may cause eutrophication which is also hazardous to the environment (Sarker et al., 2009). Under this study, seven percent farmers made pit for composting and also applied to fish pond where 10 percent farmers made pit for composting and also applied to crop field. There were three percent respondents suggested both biogas plant and cooking fuel while other three percent respondents mentioned biogas plant composting, cooking fuel, crop field \& fish culture. The existing practice of disposing droppings on road side result in loss of valuable nutrients, contamination of the surface and/or ground water, potential source of spread of poultry diseases, odor and aesthetic problems (Hossain and Ali, 2009).

Site of pit: Among pits, 44 percent situated at high land, 31 percent situated at low land and 25 percent situated at medium high land. Nitrate leaching into the ground water, non point source of phosphorous runoff into surface water bodies, and release of pathogenic microorganisms are problems encountered with improper management of pit (Hossain and Ali, 2009). The existing practice of disposing droppings in pit which situated at low land can result droppings wash out with rain water and cause environmental pollution (Alam et al., 2005). Many farmers dispose droppings to pit near poultry farms. So, the site of manure pit should be at corner of premises, preferably on downwind flow side to avoid recontamination of birds.

Upper side of the pit: Among the pits, 69 percent had upper side opened and 31 percent had upper side closed. It appeared that lack of proper knowledge of the farmers might be responsible for dumping droppings in open pit. 
Distance of the pit: Most of the farmers (36 percent) made their pit from farm in the range of 51-100 feet. Twenty three percent and twenty three percent farmers situated pit from farm in the range of 5-50 and 101-150 feet respectively. Eighteen percent farmers made pit in the range of above 151 feet.

Measurement of infected droppings: It is evident that 11 percent farmers treated infected droppings with lime prior to disposal, while 89 percent did not do any measurement.

Composting period: It is evident that 41 percent farmers were in favour of three months composting, 23 percent preferred six months and 18 percent for a period of one year to compost droppings. The remaining 18 percent farmers maintained either two week, or three week or one month respectively for composting. Rahman (2007) suggested that in 60 days, composting gradually decreased dry matter. Both composting and partial composting (defined as achieving a temperature of $55^{\circ} \mathrm{C}$ for at least three days) achieve a reduction in the pathogen load of chicken litter. Partial composting or deep stacking has the potential to pasteurise chicken litter ensuring that it is free from pathogens and providing a product at a cost likely to be acceptable for application to vegetables, fruit, crops and soils used for growing pastures for stock (Runge et al., 2007).

Heat generation during composting: It is evident that no farmer maintained proper temperature during composting. All the pathogenic microorganisms (yeasts, moulds and fungus) insects and other live organisms are destroyed due to high temperature. For proper heating litter should contain 20 to 30 percent moisture and should be stacked at 6 to 8 feet deep.

Use of droppings: Poultry waste contains a huge amount of nitrogenous substance (Jacobs et al., 2003), which enhances the plant growth and the growth of phytoplankton and zooplankton in the pond, which are the basic feed for fish. Among farmers, 31 percent used the droppings as fish feed, six percent used as both fish feed and organic farm. Droppings use as a soil fertilizer for crop production is due to the fact that it contains significant amounts of nutrients essential for plant growth (Hossain and Ali, 2009). There were 16 percent farmers used as organic fertilizer in agricultural farm, 12.5 percent gave free of cost, 12.5 percent farmers gave free of cost and also used as crop field and fish feed. Three percent farmers suggested for biogas, fish feed and sale where other three percent used as fish feed, organic fertilizer, biogas and sale. Biogas is generated through anaerobic decomposition of organic wastes. Biogas production technology is well developed around the globe. There were 16 percent farmers sold the droppings. Sarker et al., (2008) showed 20 percent farmers could not use their poultry litter for any particular work, 40 percent of them sold, 30 percent used for crop production and, 10 percent used for fish culture.
Table 2. Poultry waste utilization in study area

\begin{tabular}{lcc}
\hline Waste utilization & \multicolumn{2}{c}{ Respondents } \\
\cline { 2 - 3 } & Number & Percentage \\
\hline Fish feed & 10 & 31 \\
Fish feed and organic farm & 2 & 6 \\
Organic fertilizer in agricultural & 5 & 16 \\
farm & & \\
Give at free cost & 4 & 12.5 \\
Give at free cost, crop field and fish & 4 & 12.5 \\
feed & & \\
Biogas, fish feed and cooking fuel & 1 & 3 \\
Fish feed, organic fertilizer, biogas & 1 & 3 \\
and sale & & \\
Sale & 5 & 16 \\
Total & 32 & 100 \\
\hline
\end{tabular}

Source: Field survey, 2016

DLS (2000) mentioned that droppings can be used as feed ingredient for cattle and as a fuel in powerhouse. Droppings could be used as material of compost for land application of crop nutrients, animal refeeding, bio energy production, etc.

Droppings collected at free of cost: Among the free of cost collector, 67 percent were fisheries, 20 percent crop farmers, and rest 13 percent was crop plus fisheries farmers.

Droppings buyer: Among the buyers, 70 percent was involved with cultivating fish, 10 percent crop farmers and the rest 20 percent was crop plus fish farmer.

Seasonal price: Fifty seven percent farmers received maximum droppings price in summer (Tk $53-250 / 50 \mathrm{~kg}$ bag), while 29 percent in rainy and 14 percent in winter season. According to farmers opinion, due to temperature rising fish growth is increasing rapidly in summer season so poultry droppings has more demand in this season.

Knowledge about hygiene: About 53 percent percent people had knowledge for hygienic condition during dropping handling, among them 63 percent farmers clean regularly and 37 percent farmers clean regularly and spray $\mathrm{CaO}$. They also used savlon, potash, bleaching powder, etc. for cleaning purpose. Rest 47 percent percent people had no knowledge about it. Hoque (2013) stated that only 10 percent farmer had sound knowledge on environment and waste management and highest 66 percent farmer's knowledge had poor.

Harmful bacteria, particularly E. coli and Salmonella may be present in poultry manure. So, be sure to take precautions when handling poultry litter to minimize potential health risks. Among all respondents, only 19 percent farmers used gloves in dropping handling where 81 percent do not use it. 
Advice for best waste management: Best waste management is an important issue in poultry production because it is essential to minimize stress on chickens and to reduce the risk and impact of a disease on the flock. But in Bangladesh, it is not efficient. In the study area, only 19 percent farmers got advice regarding waste management from experts and other farmers while 81 percent did not know about it.

Constraints of waste management: The study shows 89 percent of the farmers were concerned that waste management needs extra cost where 11 percent replied that it is no needed at all.

There were 32 farmers thought waste management needs extra cost. Among the specific costs involved, 38 percent farmers mentioned labor cost and labor price and 31 percent farmers said time to manage waste. Twenty five percent farmers replied for labor cost and six percent mentioned labor cost and lack of knowledge. Hossen et al. (2015) showed 24 percent farmer mentioned financial problem as barrier of poultry waste management.

Profitability of Poultry Production: In this chapter, all the components of cost and returns of poultry production and also waste management are briefly discussed. Now, the overall cost items identified for poultry productions were as follows:

1. Variable Costs

These are the costs that vary with the level of output. These include:
a) Cost of human labor
b) Cost of feed
c) Cost of medicine
d) Cost of electricity for variable inputs
e) Waste managing variable cost
- Cost of waste cleaning
- Cost of waste application to crop field and fish pond 2. Fixed Costs

These are the costs that do not vary with the level of output. These include:

f) Cost of shed making

g) Cost of cage making

h) Cost of bedding materials and feeder

i) Cost of electricity

j) Land use cost

k) Waste managing fixed cost

- Cost of pit making

- Cost of tools

1) Interest on operating capital

Estimation of variable cost: Variable costs are incurred because of the costs of using the variable inputs. These costs vary with the level of production. There are some variable inputs like cost of human labor, cost of feed, cost of medicine, cost of electricity use, cost of waste cleaning and cost of waste application to crop field and fish pond (Table 3).
Table 3. Variable cost per farm per year for poultry production

\begin{tabular}{lcc}
\hline \multicolumn{1}{c}{ Item of variable costs } & $\begin{array}{c}\text { Total } \\
\text { cost }\end{array}$ & $\begin{array}{c}\text { \% of total } \\
\text { variable cost }\end{array}$ \\
\hline Labor cost & 10,356 & 4.76 \\
Cost of feed & $1,84,002$ & 85.00 \\
Cost of medicine & 13,761 & 6.00 \\
Electric bill for variable inputs & 7,136 & 3.28 \\
Waste managing cost & & \\
$\begin{array}{l}\text { a. Cost of waste cleaning } \\
\text { b. Cost of waste application }\end{array}$ & 1,834 & 0.84 \\
$\quad$ to crop field and fish pond & 265 & 0.12 \\
Total & $2,17,355$ & 100 \\
\hline
\end{tabular}

Source: Field survey, 2016

\section{Estimation of fixed cost}

Fixed cost are those costs which do not change in magnitude as the amount of output changes and are incurred even when production is not undertaken. In this study, cost of shed making, cost of cage making, cost of bedding materials and feeder, cost of electricity, cost of pit making and cost of tools, land use cost, and interest on operating capital were considered as fixed cost for poultry production (Table 4 ).

Table 4. Fixed cost per farm per year for poultry production

\begin{tabular}{llcc}
\hline & Item of fixed costs & Total cost & $\begin{array}{c}\text { \% of total } \\
\text { fixed cost }\end{array}$ \\
\hline a. & Shed making & $1,40,000$ & 35.61 \\
b. & Cage making & 25,464 & 6.48 \\
c. & Bedding materials and feeder & 20,200 & 5.14 \\
d. & Electricity & 40,811 & 10.38 \\
e. $\quad$ Waste managing cost & 4,200 & 1.07 \\
& a. Cost of pit making & 696 & 0.18 \\
& b. Cost of tools & $1,40,000$ & 35.61 \\
f. Land Use Cost & 21,735 & 5.53 \\
g. Interest on Operating Capital & $3,93,106$ & 100 \\
\hline
\end{tabular}

Source: Field survey, 2016

Gross cost: Gross cost was calculated by adding all costs incurred for variable inputs and fixed inputs for poultry production. On the basis of gross cost per farm per year, total variable costs for poultry farmer were Tk. $2,17,355$ and total fixed costs were Tk. 3,93,106. Thus the gross cost of poultry production was Tk. $6,10,461$.

Gross return: Gross return was calculated by multiplying the each quantity of the poultry farm and price of each farm.

Gross margin: Gross margin is the difference between total variable cost and total return. Gross margin of the enterprise was obtained by deducting total variable cost from total return i.e., Gross margin= (Gross returnVariable cost). Gross margin can be increased if the total returns increased. In the study area gross margin for poultry production was estimated at Tk. 7,32,015 (Table 5). 
Table 5. Gross margin, net return and BCR per farm per year for poultry production

\begin{tabular}{lc}
\hline \multicolumn{1}{c}{ Particular } & Value (Taka.) \\
\hline Gross Return & 949370 \\
Total Variable Cost & 217355 \\
Total Fixed Cost & 393106 \\
Gross Cost (B+C) & 610461 \\
Gross Margin (A-B) & 732015 \\
Profit/ Net return (A-D) & 338909 \\
Benefit Cost Ratio (BCR) (A/D) & 1.55 \\
(Undiscounted) & \\
\hline
\end{tabular}

Source: Author's estimation, 2016.

Net return: Net return is a useful tool to evaluate the enterprise profitability. It was calculated by deducting total cost from total return i.e., Net return= Total returnTotal production cost. Per farm, total costs for poultry production was TK. 6,10,461. Per farm gross return $9,49,370$. Per farm net return was estimated at TK. $3,38,909$. Tohura (2004) revealed that on average gross return and net return of per farm per year stood at TK. 11,76,643 and TK. 3,90,028.

Benefit cost ratio (BCR): Benefit cost Ratio was calculated by dividing gross return by gross cost of the poultry farm. It is a measure to see the efficiency of resource use. Here benefit cost ratio was used to see the profitability of farm production. Table 7.3 shows that BCR was estimated 1.55 implying that Tk. 1.55 would be earned by investing every Tk. 1.00 in poultry production. Saha (2015) assessed the BCR of per farm per year poultry farming was 1.23.

\section{Impact of Poultry Waste on Health and Environment in the Study Area}

Neighbors' opinion: Sometime neighbor of any poultry firm suffer various problem like odor, nuisance, pollution. Here, 17 percent respondent said that their neighbor complained them and rest 83 percent never faced any complain from their neighbors.

Environmental effect: Some questions were asked them to know about the environmental aspects and impacts of poultry waste. In this study, 31 percent farmers reported facing some type of environmental problem. Rest 69 percent farmer's opinion was that they never faced any environmental problem. In a study by Hossen et al. (2015), only 16 percent farmers faced diseases related to poultry waste and the rest (84 percent) never faced any disease.

Among the farmers who faced several environmental problems, 46 percent faced gas (ammonia) and the second the highest, 18 percent of the farmers faced odor. Nine percent farmers also faced leaching and fly where other 9 percent faced odor as well as flies. Creating gas and odor is a problem for farmers while 9 percent faced it. Nine percent farmers also faced gas (ammonia) \& flies (Fig. 2).
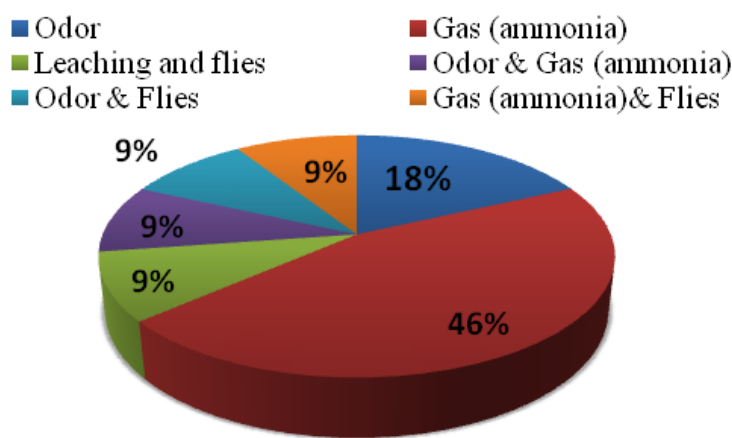

Fig. 2. Environmental effect of poultry waste faced by respondents

Health trouble: Poultry litter or manure can contain several human pathogens so bio security and good hygiene has to be practiced when handling poultry waste. Farmers were asked about their health problems related to poultry waste. In reply, 33 percent farmers responded that they faced disease outbreaks and the rest 67 percent farmers reported that they never faced any disease related to waste.

Among the farmers who faced disease, seven farmers (58 percent) suffered from gas due to high ammonia emission, two of them (17 percent) suffered from physical weakness and anorexia. Another two farmers (17 percent) suffered from eye irritation and one of them (8 percent) suffered from hydroa (leg infection). Ammonia has significant hazardous effect on the health of caretakers and to the environmental factors. Dust and ammonia have the potential to pose health problems for both chickens and staff working in the sheds. High ammonia emission from poultry houses leads to odor complaints from neighbors.

\section{Conclusion}

The poultry industry produces large quantity of litter daily which needs special attention for health and environmental safety. Improper disposal of fresh poultry litter used in agricultural farms and ponds are an environmental and public health hazard, as they can cause ammonia ingestion, eye irritation, leg infection, etc. This study also calculated profitability of poultry production considering the waste disposal costs. It was observed that poultry production remained highly profitable even after considering waste disposal costs. However, lack of awareness is the major barrier to sound waste management, and therefore, awareness building is one of the important approaches to address this issue. The concern department can take initiative to motivate the poultry producers, especially the small farm holders for disposing the litters in proper way. So, knowledge is also required for the effective planning, implementation and operation of a good waste management system. 


\section{Recommendations}

Initiate program to introduce biogas production, composting, feed etc. from poultry waste. Pit situated in high land with upper side cover is essential for proper storage system. Increasing awareness among farmers could stop to throw droppings in the road side. Encourage farmers to always wear gloves when handling manure. People who are susceptible to foodborne illnesses should avoid handling manure to prevent recontamination.

\section{References}

Alam, M.B., Hossain, M.M. and Satter M.A., 2005. Litter management of some broiler farms at Mymensingh Sadar Upazila in relation to environment. Bangladesh Journal of Environmental Science, 11 (2): 446-449.

Amin, M.A., Rahman, M.S., Howlider, M.A.R., Ahmmed, M.M., 2009. Disposal of layer droppings reared in case and impact on environmental pollution. Journal of Bangladesh Agricultural University, 7(2): 281-290. https://doi.org/10.3329/jbau.v7i2.4735

BBS, 2014: Yearbook of Agricultural Statistics of Bangladesh. Bangladesh Bureau of Statistics, Ministry of Planning, Government of People's Republic of Bangladesh, Dhaka

Collins E.R., Barker J.C., Carr L.E., Brodie H.L. and Martin J.H. 1999. Poultry waste management handbook; Natural Resource, Agriculture, and Engineering Service (NRAES), New York, USA

Dai, X.R., Saha, C.K., Ni, J.Q., Heber, A.J., Blanes-Vidal, V., and Dunn J.L., 2015. Characteristics of pollutant gas releases from swine, dairy, beef, and layer manure, and municipal wastewater. Water research, 76: 110-119 https://doi.org/10.1016/j.watres.2015.02.050 PMid:25794466

DLS (Department of Livestock Services) 2000. General information related to livestock. Monthly livestock and fisheries bulletin, published by fisheries and livestock information office, Khamarbari, Farmgate, Dhaka, Bangladesh.

Ellis, L., Love, S., Moore, A., Marti, M.E.H., 2013. Composting and Using Backward Poultry Waste in the home Garden. Publication no. CIS 1194, College of Agricultural and Life Sciences, University of Idaho.

Griffiths, N. 2007. Best practice guidelines for using poultry litter on pastures. State of New South Wales - Department of Primary Industries.

Hamid, M.A., Rahman, M.A., Ahmed, S. and Hossain, K.M., 2017. Status of Poultry Industry in Bangladesh and the Role of Private Sector for its Development. Asian Journal of Poultry Science, 11:1-13. https://doi.org/10.3923/ajpsaj.2017.1.13

Hoque, Z. 2013. Poultry waste management system in Trishal upazila. MS thesis published in Department of Environmental Science Bangladesh Agricultural University Mymensingh.

Hossain, M.M. and Ali, M.S., 2009. Wsate management of poultry farms and environmental protection in Bangladesh. In: Proceedings of 6th International Poultry Show and Seminar, Dhaka, Bangladesh, pp.199-202.

Hossen, M.S., Hoque, Z. and Nahar, B.S., 2015. Assessment of Poultry Waste Management in Trishal Upazila, Mymensingh. Research in Agriculture, Livestock and Fisheries, 2(2): 293-300.

https://doi.org/10.3329/ralf.v2i2.25013
International Finance Cooperation (IFC) 2014. Improving Productivity in the Poultry Sector in Bangladesh. Online:ifc.org/ agribusiness

Islam, M.S. 2014. Economic Study on Broiler Farming and Its Impact on Livelihood Improvement in Selected Areas of Gazipur district. MS thesis, Department of Agricultural Economics, Bangladesh Agricultural University (BAU), Mymensingh, Bangladesh.

Jacobs, R. D., Sloan, D., \& Jacob, J. 1996. Cage layer manure: An important resource for land use. Fact sheet PS-9. Dairy and Poultry Sci. Dept., Cooperative Extension Service, Inst. Food Agril. Sci. University of Florida. USA.

Miah, M.R., Rahman, A.K.L., Akanda, M.R., Pulak, A. and Rouf, M.A., 2016. Production of Biogas from Poultry Litter Mixed with the Co-substrate Cow dung. Journal of Taibah University for Science. 10(4): 497-504. https://doi.org/10.1016/j.jtusci.2015.07.007

North, M.O. and Bell, D.D. 1990. Commercial Chicken Production Manual. 4th Edition, Poultry Housing, pp.188; Cage Management, pp. 352; Waste Management, pp.881-883.

Rahman, M.A. 2007. Development of a convenient composting method using Broiler litter. MS thesis, Department of Animal Science, Bangladesh Agricultural University, Mymensingh, pp.17.

Runge, G.A., Blackall, P.J. and Casey, K.D., 2007. Chicken Litterissues associated with sourcing and use. Rural Industries Research and Development Corporation. 07/035: 10-15.

Saha, A. 2015. Inclusion of Small Farmers in Poultry Production through Feed Meal's Contractual System: A Case Study in Netrokona District. MS thesis, Department of Agricultural Economics, Bangladesh Agricultural University (BAU), Mymensingh, Bangladesh.

Saliga, R. and Skelly, J., 2013. Using Chicken Manure Safely in Home Gardens and Landscapes. Fact Sheet 13-23. University of Nevada Cooperative Extension.

Sarker, B. C., Alam, M. A., Rahman, M. M., Islam, A. F. M. T., \& Chowdhury, M. G. F. 2009. Waste management of Commercial poultry farms in Bangladesh. Journal of Innovation and Development Strategy, 2(3), 34-37.

Sarker, B.C., Alam, M.A., Rahman, M.M., Islam, A.F.M. and Chowdhury, M.G.F. 2008. Waste management of commercial poultry farms in Bangladesh. Journal of Innovation and Development Strategy, 2(3): 34-37.

Sultana, A. 2009. An Economic Analysis of Broiler Production in some selected Areas of Mymensingh District. MS thesis, Department of Agricultural Economics, Bangladesh Agricultural University (BAU), Mymensingh, Bangladesh.

Thyagarajan, D., Barathi, M., and Sakthivadivu, R., 2014. Risk Mitigation of Poultry Industry Pollutants and Waste for Environmental Safety. Global Journal of Science Frontier Research: Agriculture and Veterinary, 14(1): 49-56.

Tohura, S. 2004. Economics of small-scale commercial Broiler Farming in Sadar Upazila of Rangpur District. MS thesis, Department of Agricultural Economics, Bangladesh Agricultural University (BAU), Mymensingh, Bangladesh.

Williams, C.M., Barker J.C., Sims J.T., 1999. Management and utilization of poultry wastes. Newyork. USA. pp. 162. https://doi.org/10.1007/978-1-4612-1528-8_3

Zinn, R.A., Barajas, R., Montano, M., Shen, Y., 1996. Protein and energy value of dehydrated poultry excreta in diets for feedlot cattle. Journal of Animal Science, 74: 2331-2335. https://doi.org/10.2527/1996.74102331x PMid:8904699 